\title{
Phytochemicals as a potential source for anti- microbial, anti-oxidant and wound healing - a review
}

\begin{abstract}
Phytochemicals are known for their therapeutic properties in treating various diseases and disorders. It also holds great promise for discovery and development of new pharmaceuticals in diverse human ailments. A large number of medicinal plants are claimed to possess the anti-biotic, anti-oxidant and wound healing properties in the traditional system. The phytochemical investigations of traditionally used medicinal plants have shown the diversified useful compound classes like alkaloid, phenolic, tannin, terpene, steroid, flavonoid, glycoside, and fatty acid. These phytochemical components play an important role in scavenging free radicals, fighting infection and promoting the faster wound-healing process. Phytochemicals can serve as a cost-effective alternative therapeutic agent for human diseases. This review mainly focuses on phytochemicals and their role as antimicrobial, anti-oxidant and wound healing agent.
\end{abstract}

Keywords: phytochemicals, wound healing, anti-microbial, anti-oxidant
Volume 2 Issue 2 - 2018

\author{
Rex Jeya Rajkumar S,' Muthukumar Nadar \\ MSA,' Paulraj Mosae Selvakumar ${ }^{2}$ \\ IDepartment of Biosciences and Technology, Karunya University, \\ India \\ 2Department of Chemistry, Karunya University, India
}

Correspondence: Paulraj Mosae Selvakumar, Department of Chemistry, Karunya University, Coimbatore, Tamilnadu, 64 I I 4, India,Tel+91720086 7087, Email pmosae@gmail.com

Received: August 22, 2017 | Published: March 15, 2018

\section{Introduction}

Higher plants have provided the necessities of life such as food, shelter, and clothing to humanity from the very beginning of human civilization. In addition to that, they have also been the most important source of medicine for the treatment of various ailments since time immemorial. Although there has been considerable development in the areas of synthetic drug chemistry and antibiotics, plants still occupy an important place in the traditional and modern system of medicine. Realizing the toxic effects of the synthetic drugs, the herbal medicine and the foods that derived from plants has become an alternative even in well-developed countries. Traditional medicinal plants with rich medicinal value are utilized as folk remedies and as a pharmaceutical formulation in the modern system of medicine. Some of the main phytochemicals that medicinal plants contain includes polyphenols, alkaloids, flavonoids, steroids, tannins, and terpenoids. ${ }^{1}$

The ancient development of traditional medicinal systems can be traced back to some 60,000 years ago. ${ }^{2}$ All well-developed countries have been using herbal drugs ${ }^{3}$ and according to the WHO, almost $75 \%$ of the world's population has incorporated the use of medicinal products in their life as an alternate of allopathy drugs. ${ }^{4}$ It is noted that $35 \%$ of all drugs suggested and prescribed today are obtained from medicinal plants. ${ }^{4,5}$

Among the modern drugs in use today, about $40 \%$ are of natural origin. ${ }^{6}$ Due to advancement in the newer technologies, the production of plant-derived crude drugs for use as herbal remedies or raw materials in the pharmaceutical industry has increased manifolds. The drugs of natural origin used in modern medicine are pure, chemically well-defined compounds that are either used directly or are modified after suitable chemical or microbiological methods before their use as a drug.

Herbal medicines with rich bioactive phytochemicals could be useful and alternative therapeutic agents for the people who live in places where conventional drugs cannot be supplied to or who cannot afford conventional treatment. ${ }^{7,8}$ Still, modern scientific methods must evaluate the therapeutic effects of specific herbal compounds. ${ }^{9}$

\section{Phytochemicals and its classification}

Phytochemicals are what natural bioactive compounds that appear to have significant physiological effects in the human body and they cover a wide range of chemical entities such as, flavonoids, polyphenols, saponins, steroids, vitamins, among others. Phytochemicals are classified as primary or secondary constituents, depending on their role in plant metabolism (Figure 1) (Figure 2).

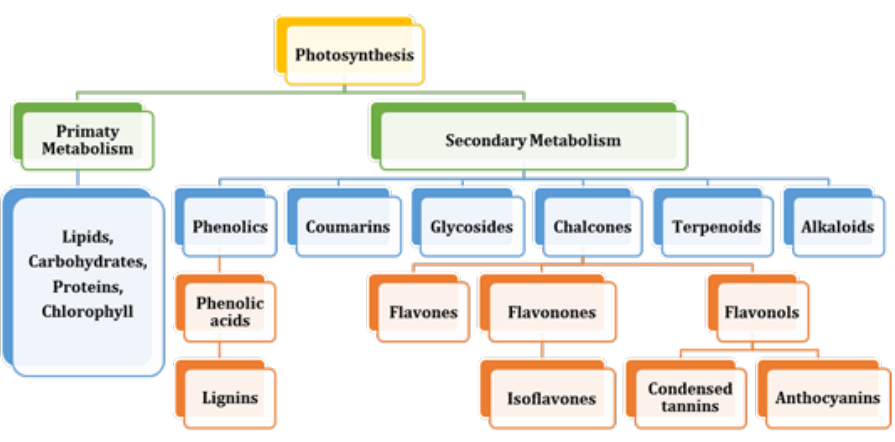

Figure I Relationship between primary and secondary metabolism in plants.

\section{Alkaloids}

Alkaloids contain heterocyclic nitrogen atoms, are basic in character which formed salts with an acid. Almost all the alkaloids have a bitter taste. Alkaloids are classified depending on the type of heterocyclic ring system present in the molecule (Table 1).

\section{Flavonoids}

Flavonoids are polyphenolic compounds that are ubiquitous among vascular plants and occur as aglycones, glucosides, and methylated derivatives. The six-membered ring condensed with the benzene ring is either pyrone (flavones and flavonols) or its dihydro derivative (flavanones and flavan-3-ols). The position of the 
benzenoid substituent divides the flavonoids into two classes: flavone and isoflavone. Most flavonoids occur naturally associated with sugar in conjugated form and, within any one class, may be characterized as monoglycosidic, diglycosidic, etc. The glycosidic linkage is normally located at position 3 or 7 and the carbohydrate unit can be L-rhamnose, D-glucose, galactose or arabinose. ${ }^{10}$

\begin{tabular}{|c|c|}
\hline \multirow{12}{*}{$\begin{array}{l}\text { Classification of } \\
\text { Phytochemicals }\end{array}$} & Alkaloids \\
\hline & Anthocyanins \\
\hline & Coumarins \\
\hline & Flavonoids \\
\hline & Fatty acids \\
\hline & Lactones \\
\hline & Polypeptides \\
\hline & Polyphenols \\
\hline & Tannins \\
\hline & Terpenoids \\
\hline & Saponins \\
\hline & Sterols \\
\hline
\end{tabular}

Figure 2 Classifications of Phytochemicals.

Table I Class of alkaloids

\begin{tabular}{ll}
\hline Class & Compounds \\
\hline Pyrrolidine alkaloids & Hygrine \\
Pyridine alkaloids & Coniine, Piperine, Isopelletierine \\
Pyrrolidine-pyridine alkaloids & Myosmine, Nicotine \\
Pyridine-piperidine alkaloids & Anabasine \\
Quinoline Alkaloids & Quinine, Primaquinine \\
Isoquinoline alkaloids & Narcotine, Papaverine, Morphine, Codeine, \\
\hline
\end{tabular}

\section{Phenolic acids}

Phenolic acids possess one carboxylic acid functional group. Naturally occurring phenolic acids contain two distinctive carbon frameworks: the hydroxycinnamic and hydroxybenzoic structures. Hydroxycinnamic acid compounds are produced as simple esters with glucose/hydroxycarboxylic acids. Biogenetically, phenolic compounds proceed of two metabolic pathways: the shikimic acid pathway where, mainly, phenylpropanoids are formed and the acetic acid pathway, in which the main products are the simple phenol ${ }^{11}$ Most plants phenolic compounds are synthesized through the phenylpropanoid pathway. ${ }^{12}$ The combination of both pathways leads to the formation of flavonoids, the most plentiful group of phenolic compounds in nature (Table 2). ${ }^{11}$

\section{Saponins}

Saponins are a group of plant secondary metabolites found to form stable foam in aqueous solutions such as soap. Saponins include compounds that are glycosylated steroids, triterpenoids, and steroid alkaloids. Two main types of steroid aglycones are known, spirostan and furostan derivatives. The carbohydrate part consists of one or more sugar moieties containing glucose, galactose, xylose, arabinose, rhamnose, or glucuronic acid glycosidically linked to a sapogenin (aglycone). Saponins that have one sugar molecule attached at the C-3 position are called monodesmoside saponins, and those that have a minimum of two sugars, one attached to the $\mathrm{C}-3$ and one at $\mathrm{C}-22$, are called bidesmoside saponins. ${ }^{13}$

Table 2 Classes of phenolic acids

\begin{tabular}{ll}
\hline Class & Compounds \\
\hline Hydroxy cinnamic acids & $\begin{array}{l}\text { P-coumaric acid, Ferulic acid, Caffeic acid, } \\
\text { Sinapic acid }\end{array}$ \\
Hydroxy benzoic acid & Gallic acid, Protocatechuic acid,Vanillic acid \\
\hline
\end{tabular}

\section{Tannins}

Tannins are a heterogeneous group of high molecular weight polyphenolic compounds with the capacity to form reversible and irreversible complexes with proteins, polysaccharides, alkaloids, nucleic acids, and minerals, etc (Figure 3 ).

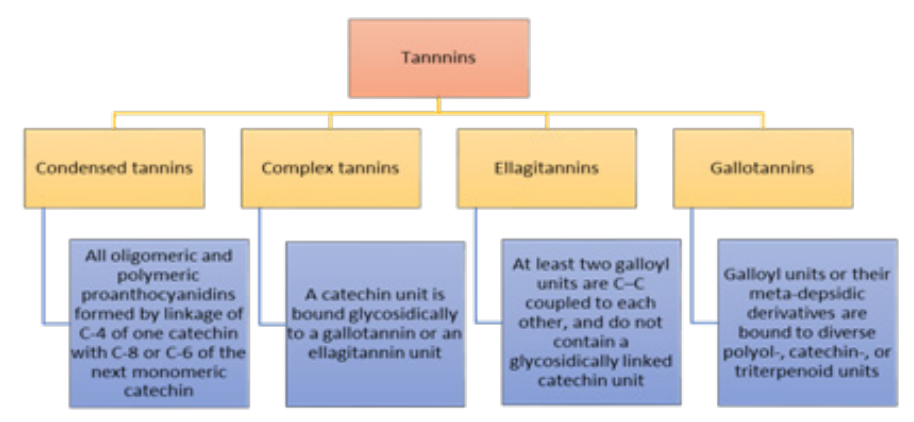

Figure 3 Classification of tannins.

\section{Terpenoids}

The terpenoids derived from five-carbon isoprene units. Most of the terpenoids have multicyclic structures that differ from one another by their functional groups and basic carbon skeletons ${ }^{14}$ Terpenes are widespread in nature, mainly in plants as constituents of essential oils. Their building block is the hydrocarbon isoprene, $\mathrm{CH}_{2}=\mathrm{C}\left(\mathrm{CH}_{3}\right)$ $\mathrm{CH}=\mathrm{CH}_{2}$. Terpene hydrocarbons, therefore, have molecular formula $\left(\mathrm{C}_{5} \mathrm{H}_{8}\right) \mathrm{n}$ and they are classified according to the number of isoprene units (Table 3) (Table 4). ${ }^{15}$

Table 3 Class of terpenes

\begin{tabular}{ll}
\hline Class & Compounds \\
\hline Monoterpenoids & $\begin{array}{l}\text { Eucalyptol, Citral, Camphor, Pinene, Limonene, } \\
\text { Geranyl pyrophosphate, } \\
\text { Cembrene, Kahweol, Taxadiene, Cafestol. Retinol, } \\
\text { Retinal, Phytol }\end{array}$ \\
Triterpenes & Lanosterol, Squalene \\
Tetraterpenoids & alpha, beta and gamma carotenes \\
Sesquiterpenes & Artemisinin, Bisabolol, Fernesol, Eudesmol, \\
Hemiterpenoids & Isoprene, Isovaleric acid, Prenol
\end{tabular}


Table 4 Solvents used to extract major phytochemicals

\begin{tabular}{|c|c|c|c|c|c|c|}
\hline Acetone & Chloroform & $\begin{array}{l}\text { Dichloro- } \\
\text { Methanol }\end{array}$ & Ethanol & Ether & Methanol & Water \\
\hline \multirow[t]{11}{*}{ Flavonols } & Flavonoids & Terpenoids & Alkaloids & Alkaloids & Anthocyanins & Anthocyanins \\
\hline & Terpenoids & & Flavonol & Coumarins & Flavones & Lectins \\
\hline & & & Polyacetylene & Fatty acids & Lactones & Polypeptides \\
\hline & & & Polyphenols & Terpenoids & Polyphenols & Saponins \\
\hline & & & Sterols & & Phenones & Starches \\
\hline & & & Tannins & & Quassinoids & Tannins \\
\hline & & & Terpenoids & & Saponins & Terpenoids \\
\hline & & & & & Tannins & \\
\hline & & & & & Terpenoids & \\
\hline & & & & & Totarol & \\
\hline & & & & & Xanthoxyllines & \\
\hline
\end{tabular}

\section{Phytochemical as biomedicine}

A natural product can be an entire organism such as a plant or an animal or a microorganism or it can also be a part of it such as a leaf or a flower of a plant or an isolated gland or an organ of an animal. ${ }^{6}$ The healing or poisonous properties of plants have been explored since long by humanity. The knowledge of these plants has been passed from one generation to another. Herbal medicines and their preparations have been commonly used for more than 1000 years in countries like India, Japan, China, Korea, etc., ${ }^{16}$ The wound healing properties of the various phytochemicals are due to their inhibition of platelet aggregation, anti-inflammatory, anti-microbial, anti-oxidative activities and that reduce the risk of wound disorders. Numerous studies have been investigated the anti-microbial, antioxidant and wound healing agents in an effort to facilitate their use as phytomedicines in the pharmaceutical industry (Figure 4). ${ }^{17-31}$

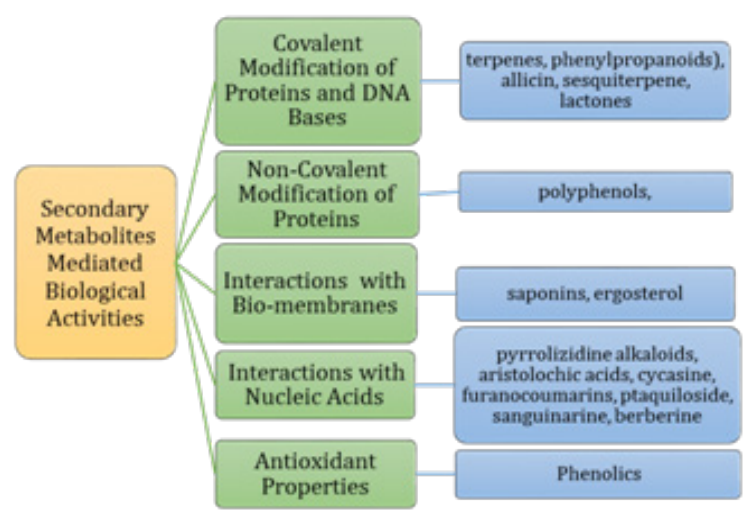

Figure 4 Secondary Metabolites mediated biological activities.

\section{Anti-microbial phytochemicals}

Some phytochemicals are well known for their anti-microbial properties which are of major significance to a therapeutic level of treatments. ${ }^{32}$ Medicinal plant and their extracts were widely used for the treatment of all the infectious diseases and it forms the basis for all Indian systems of medicine. The effect of medicinal plant and their extracts on microbial pathogens has been studied worldwide. ${ }^{33,34}$ The screening of natural products and extracts for anti-microbial activity has clearly shown that medicinal plants represent a potential source of newly invented antibiotics. ${ }^{35}$ The genetic ability of microbial pathogens becoming resistant to widely used antibiotics became a major threat to humans worldwide. ${ }^{36}$ The use of medicinal plants and the phytochemical components contained in their extract can be a significant alternate in therapeutics and also be helpful in dealing with the threats of multi-drug resistant microbial pathogens. ${ }^{37}$ Crude extracts of some traditionally known herbal drugs are used to control microbial pathogens. ${ }^{38}$ Anti-microbial components are used in the microbial infection management which may occur in acute and chronic wounds (Figure 5) (Figure 6). ${ }^{39}$

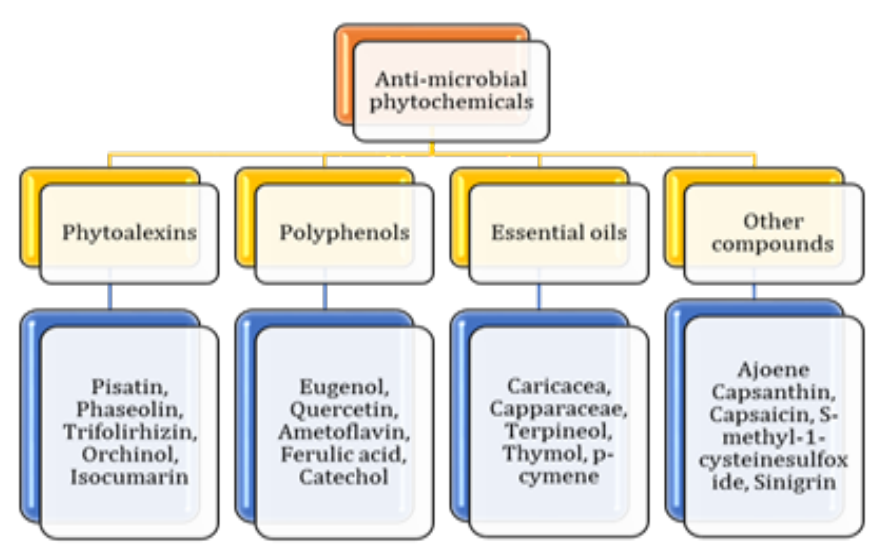

Figure 5 Anti-microbial phytochemicals.

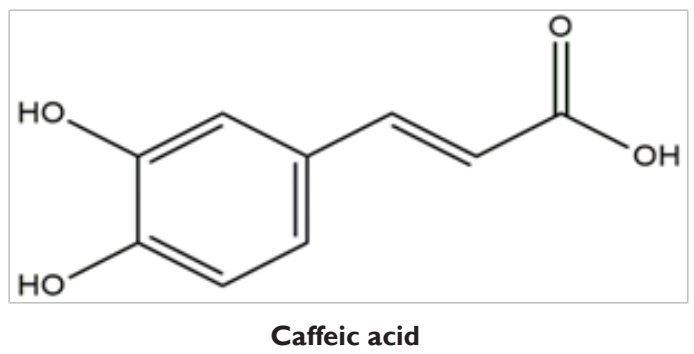




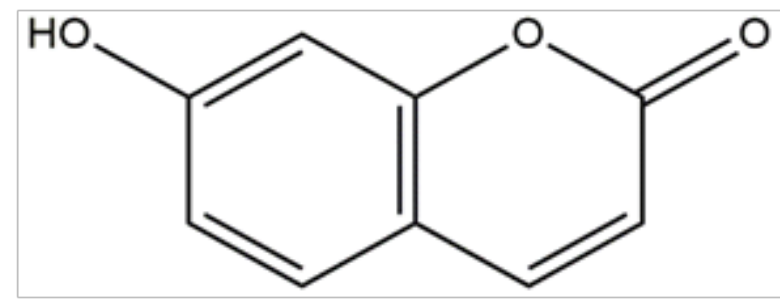

7-hydroxycoumarin<smiles>Oc1cc(O)c2c(c1)OC(c1ccc(O)c(O)c1)C(O)C2</smiles>

Catechin

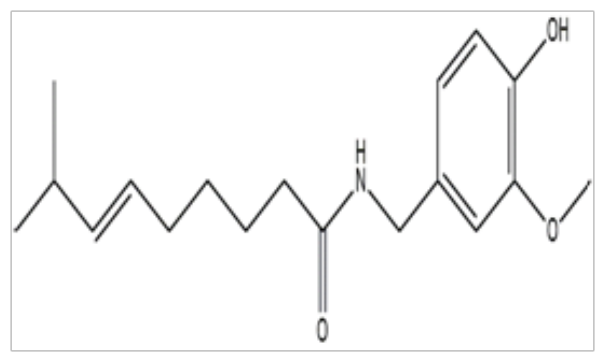

Caspacin<smiles>COc1ccc2cc3[n+](cc2c1OC)CCc1cc2c(cc1-3)OCO2</smiles>

Berberine

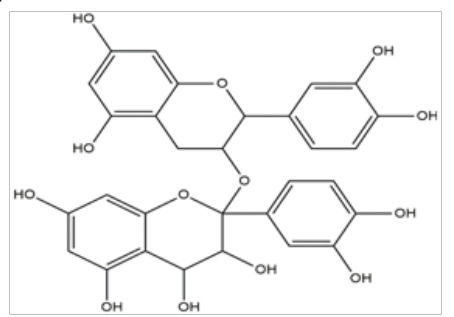

Procyanidin<smiles>Oc1ccccc1O</smiles>

Catechol

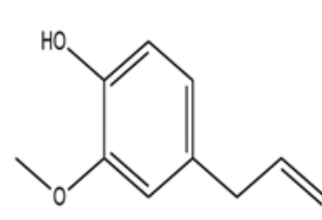

Eugenol<smiles>CC1CCC(C(C)C)C(O)C1</smiles>

Menthol
Figure 6 Phytochemical compounds as antimicrobial agents.

\section{Anti-oxidant phytochemicals}

Anti-oxidant is a defence system through which a human body is getting protected from oxidative damage of free radicals. ${ }^{40}$ Excess in the generation of free radicals leads to cellular stress that can damage the DNA, proteins, and other cellular structure and function. ${ }^{41}$
Reactive Oxygen Species (ROS) are a group of free radicals, reactive molecules, and ions that are derived from $\mathrm{O}_{2}$. ROS include free radicals such as superoxide anion $\left(\mathrm{O}_{2}{ }^{--}\right)$, hydroxyl radical $\left({ }^{\circ} \mathrm{OH}\right)$, as well as non-radical molecules like hydrogen peroxide $\left(\mathrm{H}_{2} \mathrm{O}_{2}\right)$ and so forth. Medicinal plants have become the potential sources of natural anti-oxidants and produce a number of anti-oxidative compounds that have medicinal and therapeutic properties. Drug formulations that contain anti-oxidant components are widely used for the treatment and prevention of many infectious and complex diseases. It is reported that antioxidants prevent oxidative stress caused by ROS and free radicals. ${ }^{42}$ In nature, there is a wide variety of naturally occurring anti-oxidants which are different in their composition, physical and chemical properties, mechanisms and site of action. Medicinal plants rich in flavonoids, vitamins, polyphenols, and anthocyanins are reported to possess remarkable anti-oxidant activity. Anti-oxidant activity is neither restricted to a particular part of the plant nor the specific families (Figures 6-9).

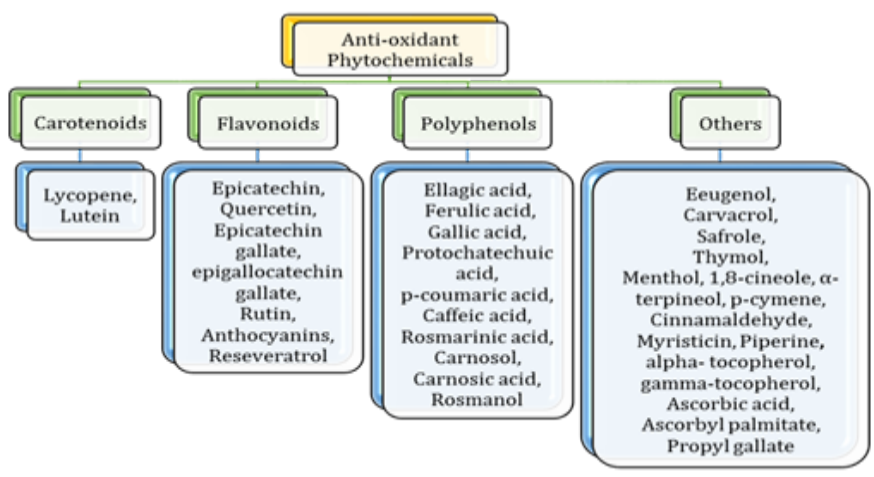

Figure 7 Anti-oxidant phytochemicals.

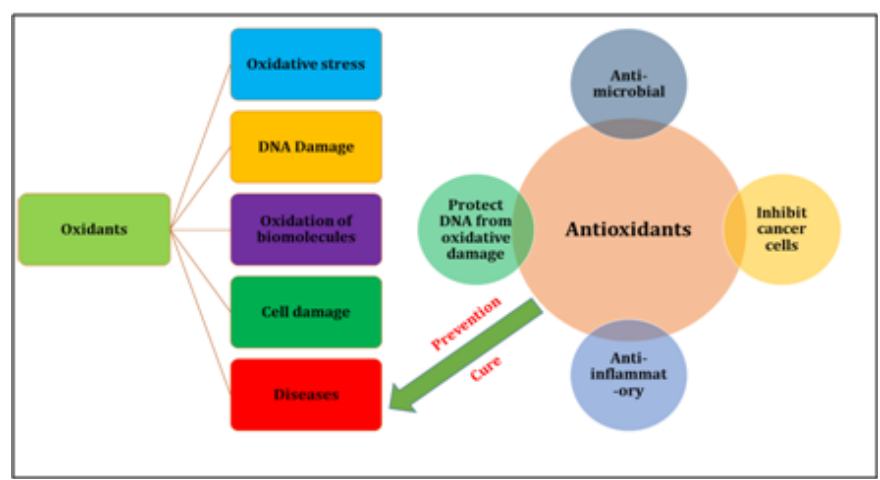

Figure 8 Role of anti-oxidants in preventing diseases.

\section{Wound healing phytochemicals}

Wound healing is a complex but a natural process characterized by inflammatory phase, proliferative phase and maturation phase. ${ }^{43}$ More than a million people suffer from burn injuries annually, $y^{74}$ Wound healing is commonly discussed in the science and medical literature and always there is a need for effective healing medication. In wound injuries, allergic reactions and skin irritations are the most important adverse effects of topical antiseptic agents and disinfectants, which reduce the rate of skin repair and increase the rehabilitation period. ${ }^{7}$ The traditional formulation of wound medicine, especially the herbal and other medicinal products deployed worldwide, are still under scientific evaluation for their properties in the treatment of wounds. 
Various herbal drugs and herbal formulations have been widely used in the treatment of wounds for years. Over the past 35 years, the knowledge regarding wound healing process has increased drastically. The development of novel and exciting technologies that accelerate normal wound healing process has come. Several natural products such as alkaloids, tannins, flavonoids, terpenes, promote the healing process. ${ }^{45}$ Herbal medicines encourage fighting against infection and accelerating the healing of wounds. The future of science and technology in wound care holds a great promise. Studies on traditional and medicinal plants confirmed that herbal formulations and the drugs derived from medicinal plants exhibit very fewer side effects than synthetic drugs. ${ }^{39,46}$ The herbal drugs and herbal formulations for wound healing are affordable and cheap (Table 5).

Table 5 Wound healing phytochemical compounds

\begin{tabular}{|c|c|c|}
\hline S.No & Source & Chemical compounds \\
\hline I & Acalypha indica & Acalyphin, acalyphamide, acalyphal acetate, aurantiamide, succinimide and flindersin \\
\hline 2 & $\begin{array}{l}\text { Anacardium } \\
\text { occidentale }\end{array}$ & Cardol, anacardic acid, anacardein, occidentoside, campesterol, B-sitosterol and Stigmasterol \\
\hline 3 & Areca catechu & Arecoline, choline, arecaine, guvacin, aricaidinecatechu and $\alpha$-catechin \\
\hline 4 & $\begin{array}{l}\text { Arnebia } \\
\text { densiflora }\end{array}$ & Shikonin, Berberine \\
\hline 5 & Berberis lyceum & Berberine \\
\hline 6 & $\begin{array}{l}\text { Calotropis } \\
\text { gigantean }\end{array}$ & Calotropin, akundarin, uscharin, calotoxin, calactin, $\alpha, \beta$ calotropeol, $\beta$-amyrin, giganteol and isogiganteol \\
\hline 7 & $\begin{array}{l}\text { Centaurea } \\
\text { ainetensis }\end{array}$ & Salograviolide \\
\hline 8 & Centella asiatica & Asiaticoside, asiatic acid, and madecassic acid \\
\hline 9 & Cleome viscosa & Viscosic acid, viscosin, cleomiscosin A, B, C \& D, cleosandrin, cleomeolide \\
\hline 10 & Curcuma longa & Curcumin \\
\hline II & $\begin{array}{l}\text { Elephantopus } \\
\text { scaber }\end{array}$ & $\begin{array}{l}\text { Sesquiterpene lactones deoxyelephantopin, isodeoxyelephantopin, scabertopin, epifriedelinol, lupeol, } \\
\text { stigmasterol }\end{array}$ \\
\hline 12 & Euphorbia hirta & Euphorbia A \& B, rutin, gallic acid, quercitrin, I-inositol, kaempferol, xanthorhamin \\
\hline 13 & Ficus bengalensis & $\begin{array}{l}\text { Bengalenoside, leucocyandin, perlargonidin, leucopelargonin, leucodelphinidin derivatives, caoutchouc, } \\
\text { tannins }\end{array}$ \\
\hline 14 & Ficus racemose & Racemosic acid, gluanol acetate, caoutchouc, tannins, ß-sitosterol, stigmasterol, friedelin, hentriacontane \\
\hline 15 & Ixora coccinea & Lupeol, fatty ester, ursolic, oleanolic, stearic, oleic, linoleic acids, sitosterol \\
\hline 16 & $\begin{array}{l}\text { Jasminum } \\
\text { auriculatum }\end{array}$ & Lupeol, jasminol \\
\hline 17 & $\begin{array}{l}\text { Lawsonia } \\
\text { inermis }\end{array}$ & $\begin{array}{l}\text { Lawsochylin A, lawsonaphthoate A, luteolin, apigenin, cytochalasin B, coumaric acid, 2-methoxy-3- } \\
\text { methyl- I,4-naphthoquinone, apiin, lawsone, apigenin, luteolin, cosmosiin }\end{array}$ \\
\hline 18 & $\begin{array}{l}\text { Morinda } \\
\text { pubescens }\end{array}$ & Morindin, morindone, rubiadin, anthraquinones \\
\hline 19 & Pinus densiflora & Pinosylvin \\
\hline 20 & $\begin{array}{l}\text { Pistacia } \\
\text { terebinthus }\end{array}$ & Masticadienonic acid, masticadienolic acid, morolic acid \\
\hline 21 & Punica granatum & granatin $B$, punicalagin, punicalin, strictinin $A$ \\
\hline 22 & Rosa indica & Indomethacin \\
\hline 23 & $\begin{array}{l}\text { Terminalia } \\
\text { bellirica }\end{array}$ & Gallo-tannic acids, termilignan, thannilignan \\
\hline 24 & Others & Borneol, Thymol, Genipin, a-Terpineol, Aucubin \\
\hline
\end{tabular}




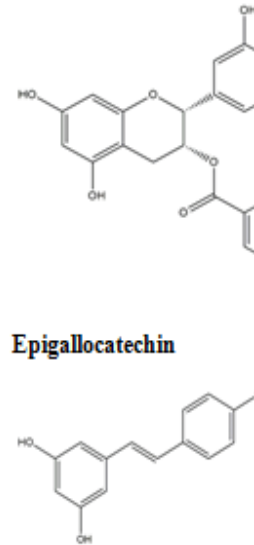

Resveratrol

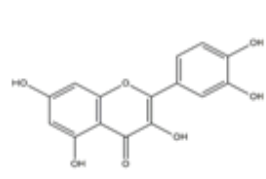

Quercetin

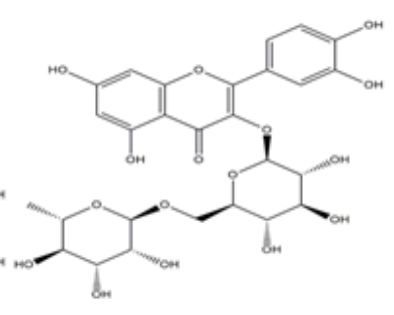

Rutin<smiles>O=C(O)/C=C/c1ccc(O)c(O)c1</smiles>

Caffeic acid

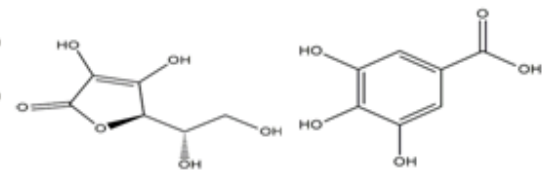

Ascorbic acid

Gallic acid

\section{In silico approach of phytochemicals- a design of better drugs}

In silico approaches are useful at the initial stage of drug discovery process. The application of QSAR is extended to molecular design, prediction of differentbiological activities, lead compound optimization and virtual screening, classification, diagnosis and elucidation of mechanisms of drug action, toxicity prediction of environmental toxicants and prediction of drug-induced toxicity. ${ }^{47}$ Phytochemistry approaches are being applied to create screening libraries that closely resemble drug-like compounds. In silico techniques such as QSAR (quantitative structure-activity relationships), pharmacophore and virtual screening play a major role in accelerating steps for the better drug design. ${ }^{48}$ QSAR models have been built for a wide variety of antimicrobial, anti-oxidant and wound healing phenolic compounds and flavonoids (such as coumarins, lignans, stilbenes, curcuminoids, and tannins) derived from traditional medicinal plants. ${ }^{49}$ It is important to stress that natural products differ from synthetic active molecules (e.g., number of aromatic rings, size, flexibility), that are mainly found in biological databases, such as PubChem ${ }^{50}$ and CHEMBL. ${ }^{51}$ Furthermore, it is a must to evaluate their datasets for compatibility (Table 6) (Table 7). ${ }^{52,53}$

Figure 9 Phytochemical compounds as antioxidant agents.

Table 6 Phytochemical compounds- structure, mechanism and therapeutic uses

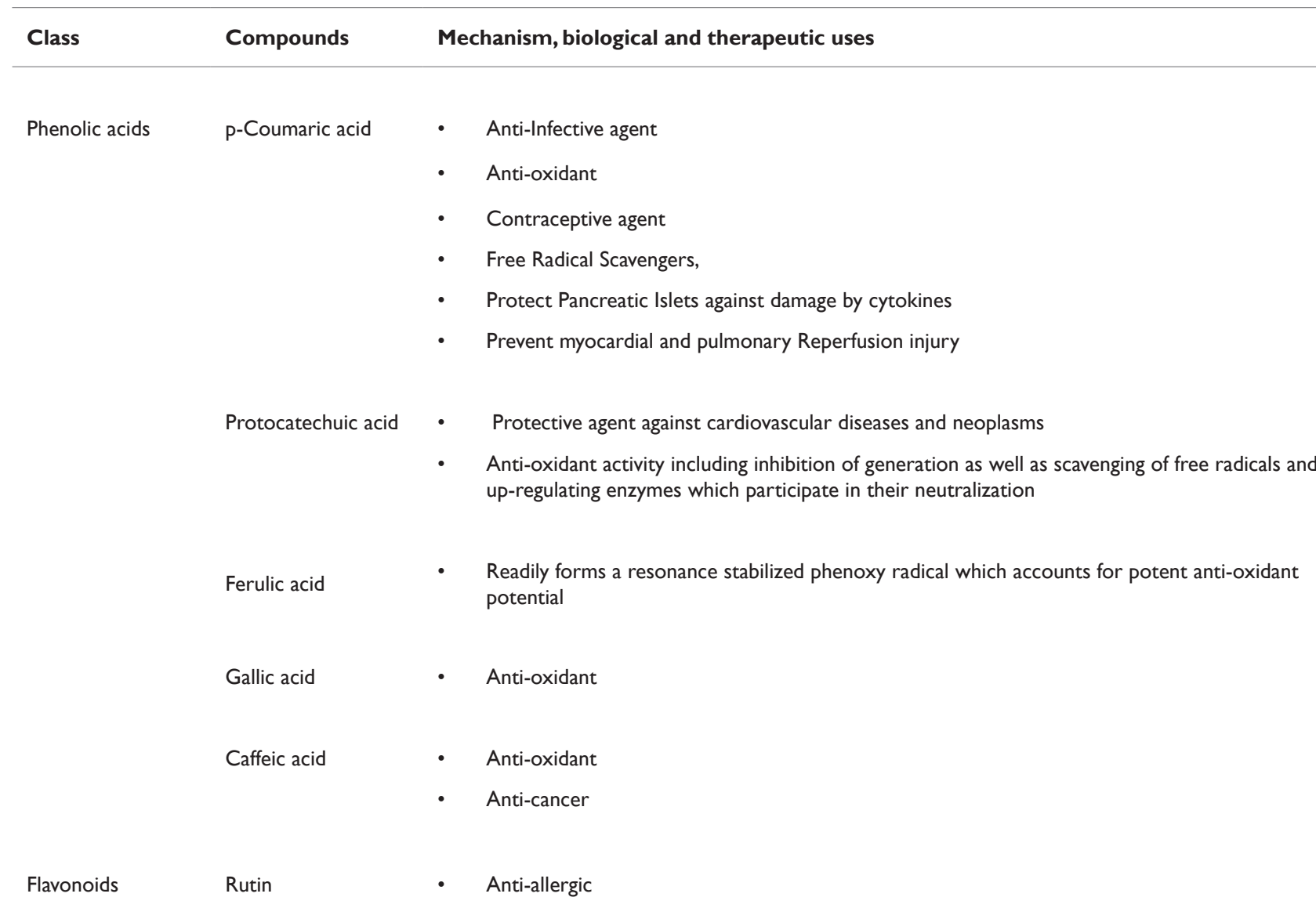


Table Continued

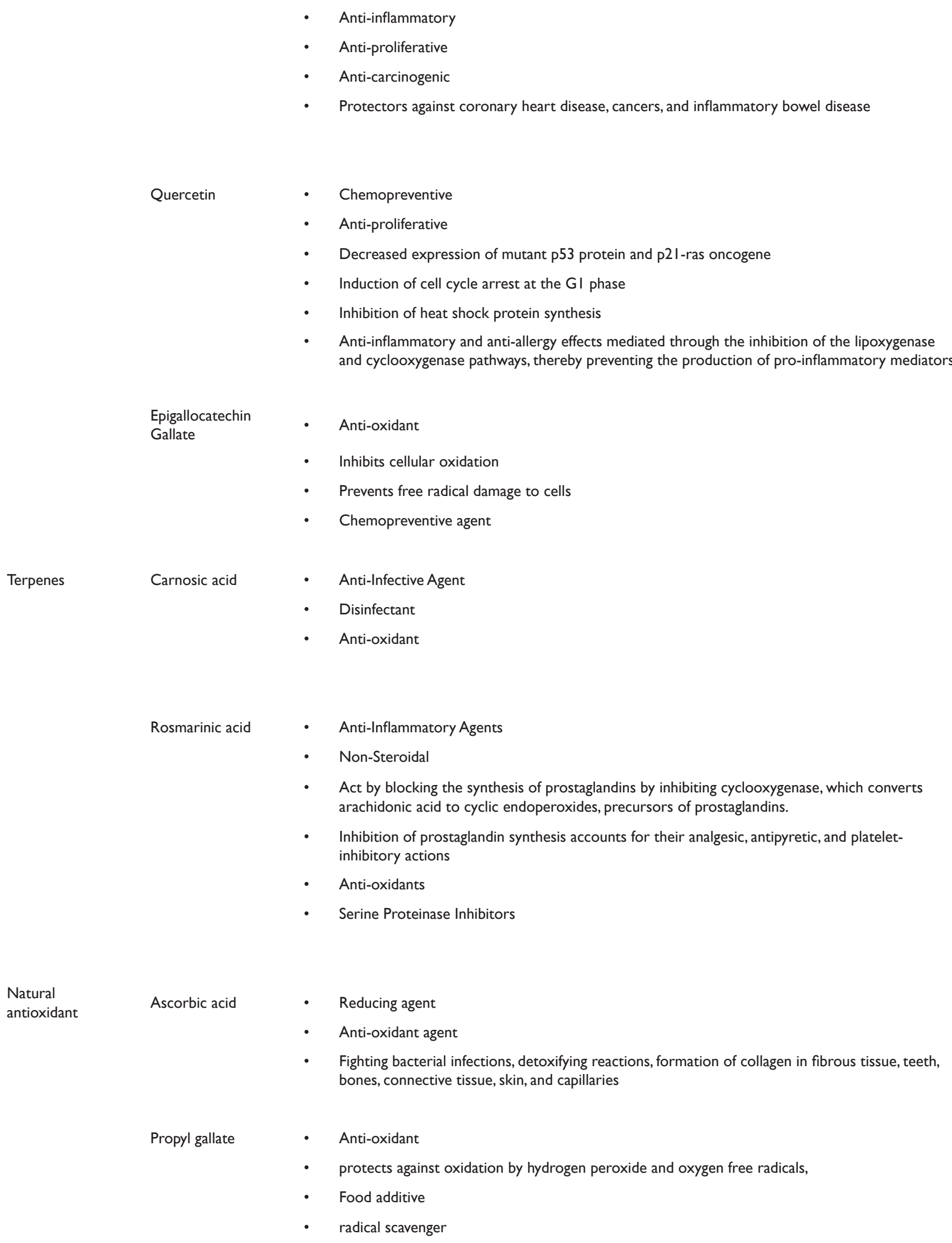


Table Continued

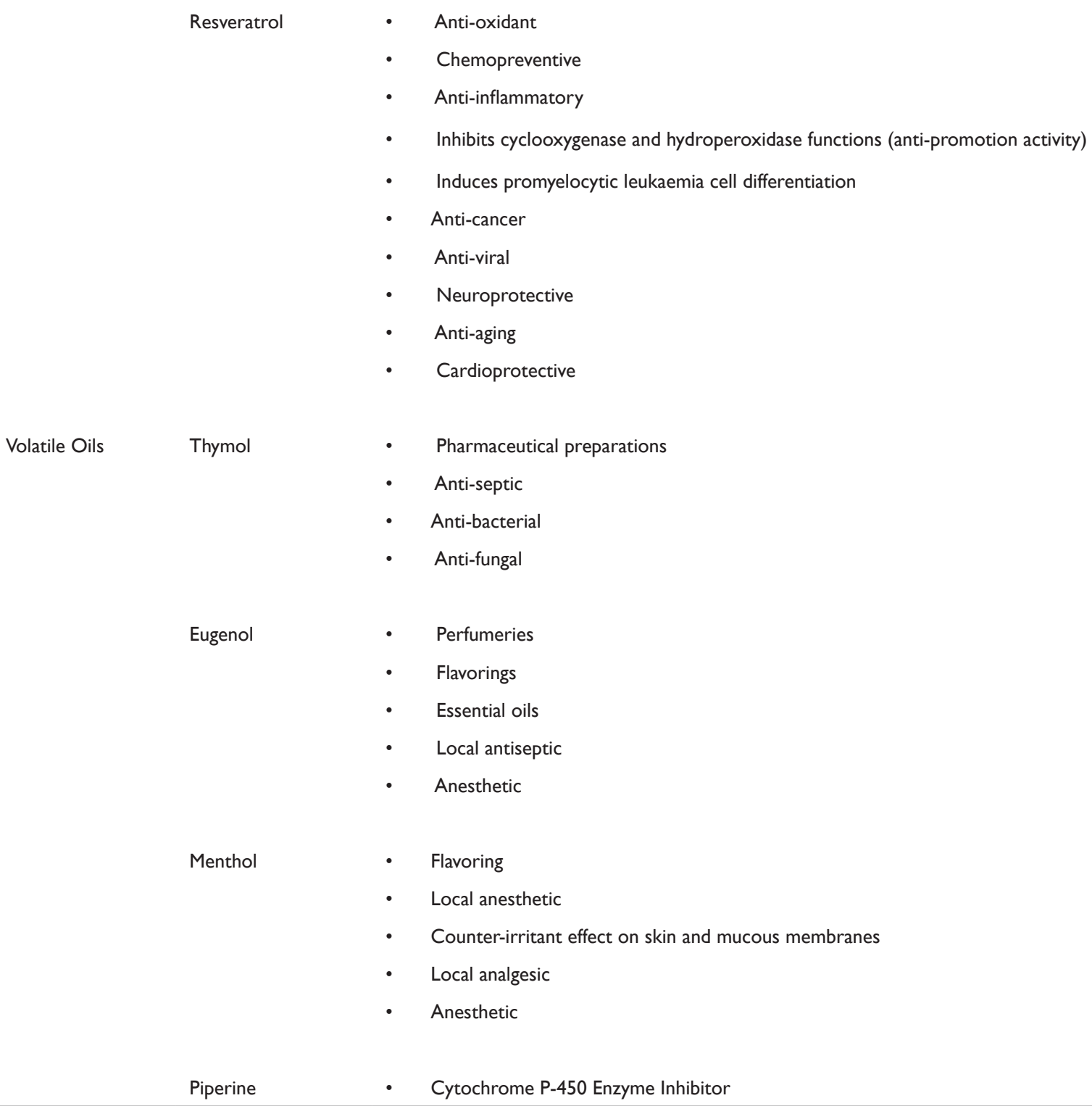

Piperine $\quad$ C Cytochrome P-450 Enzyme Inhibitor

Table 7 Phytochemicals- a potential source of dietary foods and its benefits

\begin{tabular}{|c|c|c|c|}
\hline Class & $\begin{array}{l}\text { Phytochemical } \\
\text { Compounds }\end{array}$ & Dietary Sources & Biological benefits \\
\hline \multirow[t]{5}{*}{ Carotenoids } & Beta-carotene & $\begin{array}{l}\text { Red, orange and green fruits and } \\
\text { vegetables including carrots, cooked }\end{array}$ & Inhibit cancer cell growth, \\
\hline & Lycopene & tomatoes, leafy & Work as antioxidants and \\
\hline & Lutein & greens, & improve immune response \\
\hline & Zeaxanthin & sweet potatoes, & \\
\hline & & watermelon & \\
\hline \multirow[t]{2}{*}{ Flavonoids } & $\begin{array}{l}\text { Anthocyanins, } \\
\text { Quercetin }\end{array}$ & $\begin{array}{l}\text { Apples, citrus fruits, onions, soybeans and soy } \\
\text { products coffee, tea }\end{array}$ & Inhibit inflammation and tumour growth, \\
\hline & & & $\begin{array}{l}\text { Aid immunity, Boost production of detoxifying } \\
\text { enzymes in the body }\end{array}$ \\
\hline
\end{tabular}


Table Continued

Polyphenols

Ellagic acid,

Resveratrol
Green tea, grapes, berries, citrus fruits, apples, whole grains, peanuts
Prevent cancer formation, Prevent inflammation,

Work as antioxidants

$\begin{array}{lll}\text { Terpenes } & \text { Limonene, Carnosol } & \text { Cherries, citrus fruit peel, rosemary }\end{array}$

Protect cells from becoming cancerous,

Slow cancer cell growth, Strengthen immune

function, Limit production of cancer-related hormones,

Work as antioxidant

\section{Summary}

Phytochemicals have immense potential for the management and treatment of microbial infections and wounds. Anti-microbial, antioxidant and wound healing phytochemicals encourage blood clotting, fight infection and accelerate the healing of wounds. Therefore, it is important to study and examine all options available and need to be improved. The phytomedicines are not only cheap and affordable but are safe and less toxic than allopathic drugs. Phytochemicals need to be identified and formulated for treatment and management of infections and wounds. However, there is a need for standardization, safety, and scientific evaluation before recommending phytochemicals for therapeutic purpose.

\section{Acknowledgements}

The authors are thankful to Miss. Bindu Jacob, Junior Research Fellow, UGC-MANF, Karunya University, Coimbatore, India for assisting in aligning the contents and drawing the chemical structures of the manuscript.

\section{Conflict of interest}

There is no conflict of interest.

\section{References}

1. Hill AF. Economic Botany. A textbook of useful plants and plant products. $2^{\text {nd }}$ ed. New York: McGarw-Hill Book Company Inc; 1952.

2. Solecki RS. Shanidar IV, a Neanderthal flower burial in northern Iraq Science. 1975;190(4217):880-881.

3. Lanfranco G. Popular use of medicinal plants in the Maltese Islands. Insula.1992;1:34-35.

4. Farnsworth NR, Akerele O, Bingel AS, et al. Medicinal plants in therapy. Bull World Health Organ. 1985;63(6):965-981.

5. Raskin I, Ripoll C. Can an apple a day keeps the doctor away? Curr Pharm Des. 2004;10(27):3419-3429.

6. Samuelsson G. Drugs of natural origin: A treatise of pharmacognosy (No. 615.321 S193d). Stockholm: Swedish Academy of Pharmaceutical Sciences; 2009:745-747.

7. Upadhyay NK, Kumar R, Siddiqui MS, et al. Mechanism of woundhealing activity of Hippophae rhamnoides L. leaf extract in experimental burns. Evid Based Complement Alternat Med. 2011;659705.

8. Lee G, Bae H. Therapeutic Effects of Phytochemicals and Medicinal Herbs on Depression. BioMed Research International. 2017;2017:6596241.

9. Chaudhari M, Mengi S. Evaluation of phytoconstituents of Terminalia arjuna for wound healing activity in rats. Phytother Res.
2006;20(9):799-805.

10. Pretorius JC. Flavonoids: A Review of Its Commercial Application Potential as Anti- Infective Agents. Current Medicinal Chemistry. 2003;2(4):335-353.

11. Sánchez-Moreno C. Compuestos polifenólicos: estructura y classificación: presencia en alimentos y consumo: biodisponibilidad y metabolismo. Alimentaria. 2002;329:19-28.

12. Hollman PCH. Evidence for health benefits of plant phenols: local or systemic effects? Journal of the Science of Food and Agriculture. 2001;81(9):842-852.

13. Lasztity R, Hidvegi M, Bata A. Saponins in food. Food Review International. 1998;14(4):371-390.

14. Elbein AD, Molyneux RJ. Comprehensive Natural Products Chemistry. Barton D and Nakanishi K, $1^{\text {st }}$ ed. Amsterdam: Elsevier; 1999: 3-29.

15. Langenheim JH. Higher plant terpenoids: A phytocentric overview of their ecological roles. J Chem Ecol. 20(6): 1223-1280.

16. Liang YZ, Xie P, Chan K. Quality control of herbal medicines. $J$ Chromatogr B Analyt Technol Biomed Life Sci. 2004;812(1-2): 53-70.

17. Rex Jeya RS, Sreeraj K, Muthukumar Nadar MSA. Qualitative Phytoconstituent Profile of Lobelia trigona Roxb Extracts. International Journal of PharmTech Research. 2015;8(10):47-50.

18. Nandhini J, Neeraja P, Rajkumar SRJ, et al. Comparative studies of microwave and Sol-Gel-assisted combustion methods of $\mathrm{NiFe}_{2} \mathrm{O}_{4}$ nanostructures: synthesis, structural, morphological, opto-magnetic, and antimicrobial activity. Journal of Superconductivity and Novel Magnetism. 2017;30(5):1213-1220.

19. Mosae Selvakumar P, Antonyraj CA, Babu R, et al. Green synthesis and antimicrobial activity of monodispersed silver nanoparticles synthesized using lemon extract. Synthesis and Reactivity in Inorganic, MetalOrganic, and Nano-Metal Chemistry. 2016;46(2):291-294.

20. Sherly Arputha Kiruba V, Dakshinamurthy A, Subramanian PS, et al Green synthesis of biocidal silver-activated charcoal nanocomposite for disinfecting water. Journal of Experimental Nanoscience. 2015;10(7):532-544.

21. Deena S, Dakshinamurthy A, Mosae Selvakumar P. Green Synthesis of Silver Nanoparticle Using Banana (Musa) Sap. Advanced Materials Research. 2015;1086:7-10.

22. Mariselvam R, Ranjitsingh AJA, Nanthini AUR, et al. Green synthesis of silver nanoparticles from the extract of the inflorescence of Cocos nucifera (Family: Arecaceae) for enhanced antibacterial activity. Spectrochim Acta A Mol Biomol Spectrosc. 2014;129:537-541.

23. Arputha Kiruba VS, Dakshinamurthy A, Selvakumar PM. Eco-friendly biocidal silver-activated charcoal nanocomposite: antimicrobial application in water purification. Synthesis and Reactivity in Inorganic, 
Metal-Organic, and Nano-Metal Chemistry. 2013;43(8):1068-1072.

24. Kiruba VSA, Selvakumar PM, Dakshinamurthy A. Biocidal NanoSilver Reinforced Activated Charcoal in Water Treatment. Synthesis and Reactivity in Inorganic, Metal-Organic, and Nano-Metal Chemistry. 2015;45(10):1570-1575.

25. Mariselvam R, Ranjitsingh AJA, Padmalatha C, et al. Green Synthesis of Copper Quantum Dots using Rubia cardifolia Plant Root Extracts and its Antibacterial Properties. Journal of Academia and Industrial Research. 2014;3(4):191-194.

26. Karen Kiruba K, Jesse Joel T, Lalitha S, et al. Efficacy and Comparative Evaluation of Antimicrobial Properties from the Peel of Citrus Fruits used to Treat Diabetic Foot Ulcer. Asian Journal of Biochemical and Pharmaceutical Research. 2016;6(1):151-166.

27. Selvam RM, Athinarayanan G, Nanthini AUR, et al. Extraction of natura dyes from Curcuma longa, Trigonella foenum graecum and Nerium oleander, plants and their application in antimicrobial fabric. Industrial Crops and Products. 2015;70:84-90.

28. Rex Jeya Rajkumar S, Muthukumar Nadar MSA, Paulraj Mosae S. Nanotechnology in Wound Healing-A Review. Glob J Nanomed. 2017;3(1):555605.

29. Kalaiarasi G, Rajkumar SRJ, Dharani S, et al. Cyclometallated ruthenium (ii) complexes with 3-acetyl-2 [H]-chromene-2-one derived CNS chelating ligand systems: synthesis, $\mathrm{X}$-ray characterization and biological evaluation. New J Chem. 2018;42(1):336-354.

30. Jacintha AM, Umapathy V, Neeraja P, et al. Synthesis and comparative studies of $\mathrm{MnFe}_{2} \mathrm{O}_{4}$ nanoparticles with different natural polymers by sol-gel method: structural, morphological, optical, magnetic, catalytic and biological activities. Journal of Nanostructure and Chemistry. 2017;7(4):375-387.

31. Nagesh KS, Shanthamma C. Antibacterial activity of Curculigo orchioides rhizome extract on pathogenic bacteria. African Journal of Microbiology Research. 2009;3(1):5-9.

32. Srinivasa Reddy P, Jamil K, Madhusudhan P, et al. Antibacterial activity of isolates from Piper longum and Taxus baccata. Pharmaceutical biology. 2001;39(3):236-238.

33. Ates DA, Ozlem Turgay EO. Antimicrobial activities of various medicinal and commercial plant extracts. Turk J Biol. 2003;27(3):157-162.

34. Afolayan AJ. Extracts from the shoots of Arctotis arctotoides inhibit the growth of bacteria and fungi. Pharmaceutical biology. 2003;41(1):22-25.

35. Sathishkumar P, Paulsamy S, Anandakumar AM, et al. Effect of habitat variation on the content of certain secondary metabolites of medicinal importance in the leaves of the plant, Acacia caesia Willd. Advances in Plant Sciences. 2009;22(2):451-453.

36. Basso K, Margolin AA, Stolovitzky G, et al. Reverse engineering of regulatory networks in human B cells. Nat Genet. 2005;37(4):382-390.

37. Kubo M, Kimura Y, Shin H, et al. Studies on the antifungal substance of crude drug (II). On the roots of Polygonum cuspidatum Sieb. et Zucc. (Polygonaceae). Shoyakugaku Zasshi. 1981;35:58-61.
38. Rhoads DD, Cox SB, Rees EJ, et al. Clinical identification of bacteria in human chronic wound infections: culturing vs. $16 \mathrm{~S}$ ribosomal DNA sequencing. BMC Infect Dis. 2012;12:321.

39. Rajkapoor B, Burkan ZE, Senthilkumar R. Oxidants and human diseases: role of antioxidant medicinal plants-a review. Pharmacologyonline. 2010;1:1117-1131.

40. Syed SR, Mustafa SM, Jaafar FM, et al. Phenolic content and antioxidant activity of fruits of Ficus deltoidea var Angustifolia Sp. Malasiyan. Journal of Health Sciences. 2009;13(2):146-150.

41. Pham-Huy LA, He H, Pham-Huy C. Free radicals, antioxidants in disease and health. Int J Biomed Sci. 2008;4(2):89-96.

42. Sidhu GS, Mani H, Gaddipati JP, et al. Curcumin enhances wound healing in streptozotocin induced diabetic rats and genetically diabetic mice. Wound Repair Regen. 1999;7(5):362-374.

43. Ezzati A, Bayat M, Taheri S, et al. Low-level laser therapy with pulsed infrared laser accelerates third-degree burn healing process in rats. $J$ Rehabil Res Dev. 2009;46(4):543-554.

44. Suguna L, Chandrakasan G, Ramamoorthy U, et al. Influence of honey on biochemical and biophysical parameters of wounds in rats. Journal of Clinical Biochemistry and Nutrition. 1993;14(2):91-99.

45. Kumar B, Vijayakumar M, Govindarajan R, et al. Ethnopharmacological approaches to wound healing - exploring medicinal plants of India. $J$ Ethnopharmacol. 2007;114(2):103-113.

46. Selassie CD. History of quantitative structure-activity relationships. In: Abraham DJ, editor. Burger's medicinal chemistry and drug discovery. New York: John Wiley; 2003;1-48.

47. Kar S, Roy K. QSAR of phytochemicals for the design of better drugs. Expert opinion on drug discovery. 2012;7(10):877-902.

48. Mitra I, Saha A, Roy K. Exploring quantitative structure-activity relationship studies of antioxidant phenolic compounds obtained from traditional chinese medicinal plants. Molecular Simulation. 2010;36(13):1067-1079.

49. Li Q, Cheng T, Wang Y, et al. PubChem as a public resource for drug discovery. Drug Discov Today. 2010;15(23-24):1052-1057.

50. Gaulton A, Bellis LJ, Bento AP, et al. ChEMBL: a large-scale bioactivity database for drug discovery. Nucleic Acids Res. 2012;40(Database issue):D1100-D1107.

51. Feher M, Schmidt JM. Property distributions: differences between drugs, natural products, and molecules from combinatorial chemistry. $J$ Chem Inf Comput Sci. 2003;43(1):218-227.

52. Sharma P, Jha AB, Dubey RS, et al. Reactive oxygen species, oxidative damage, and antioxidative defense mechanism in plants under stressful conditions. Journal of botany. 2012;1-26. 